\title{
MUSICAL INSTRUMENTS (APPEARANCE, TYPES, FUNCTIONS) REFLECTED IN ARCHEOLOGICAL EXCAVATIONS AND WRITTEN SOURCES
}

\author{
Abdupatto Ahmadjonovich Ibragimov \\ Head Of The Department Of Music Education Namangan State University,, Uzbekistan \\ Sardor Sayfitdinovich Bannoev \\ Master, Namangan State University, Uzbekistan \\ Gulomjon Boqievich Imomberdiev \\ Master, Namangan State University, Uzbekistan
}

\section{ABSTRACT}

Central Asian scholars' treatises on music, fiction, and painting allow us to some extent restore some of the broken links in the long chain of historical development of Uzbek folk instruments that have survived to the present day. Hundreds of years have passed, and musical instruments have survived to this day, taking their place in solo, ensemble, and orchestral performance.

KEYWORDS: - Fiction, musical instruments, sources, work, analysis, masnas, masna.

\section{INTRODUCTION}

In ancient times, the famous thinker of the East Sayfuddin Urmavi developed the system of musicology. He was known as a master musician, singer and master composer. Based on his experiments in Udda, the scientist stated his theoretical rules. In Urmavi's Book of Piety, the oud is said to be the most popular and most modern of the musical instruments. Ud had five pairs of strings and 7 status (ladi) in the order of a quarter. The strings are called bam, masnas, masna, zir, and the highest hadd. The improved double-stranded oud has retained its structure in recent times. Sherazi (1236-1311), Jami (15th century), al-Husseini, Maraghi, and Ibn Sina also wrote about the five twin strings and seven maqams (ladas) of Ud that were tuned to the quartet. A complete sketch of the oud handle given in Jami's "Musical Booklet" gives a complete picture of how to set it up. According to the scientist, the existing 12 maqoms are the basis of ancient mature music. Focusing on the impact of community music on listeners, he believes it has profound spiritual and spiritual 
CURRENT RESEARCH JOURNAL OF PEDAGOGICS 2(12): 82-89, December

2021 DOI: https://doi.org/10.37547/pedagogics-crjp-02-12-17

ISSN 2767-3278

(C)2021 Master Journals

Crossref doi) 81 Google

Accepted $18^{\text {th }}$ December, 2021 \& Published 23 th December, 2021

significance.[1]

The pamphlets created in the XIII-XVII centuries give descriptions of stringed instruments such as chang, kanun, nuzkha, rubob, tanbur, as well as descriptions of damli.

Darvish Ali's (17th century) Bukhara pamphlet on music can serve as a source of information on traditional instruments. It contains rare information about the culture of music, in particular, the instruments available in the major cities of Central Asia, as well as talented performers.

Darvish Ali's treatise is a valuable source for studying Central Asian music of the 16th and 17th centuries. The play tells the creative biographies of famous singers, musicians and composers.

Darwish Ali, like his predecessors, called the udni, which is considered the best among stringed mizrob instruments in terms of its vibrating tone, the "king" of the instruments. According to the pamphlet, it is dedicated to Zuhra, the patron saint of dust instruments.

The described powder had twenty-six strings and seven curtains for the performance of the seven maqoms. In addition, the pamphlet mentions such instruments as law, rubab, kobiz, gijjak, music, ekbon-nay, (damli, leather), ruhavza (six-stringed nokhunli), which is widespread in China.[2]

Seven of the instruments described by Darwish Ali, tanbur, chang, kanun, ud, rubab, kobiz, and gijjak, were common instruments at that time.

Darvish Ali's data confirms the idea that in the practice of music, the ensemble originally used stringed and stringed instruments that produced the appropriate calories. The pamphlet mentions the names of the dustman Dilorom, the flute players Abduqadir and Khoja Abu Abdullah, Mawlana Qasimi-Rabbani, Sultan-Ahmadi "crazy" rubabs, brothers Sheikh Abu - Bakri
Rabbani and Sheikh Behduchi, wise jurist Sheikh Shamsi Rabbani and many other famous masters. The testimony of Darvish Ali is also valuable in that most of the instruments he recorded (flute, trumpet, dust, law, rubab, tanbur, gijjak, kobiz, doyra, drum, ud) were used in modern Uzbekistan, Tajikistan and other Central Asian republics, as well as in Azerbaijan. has survived to our day and is improving. For a long time, these musical instruments have a strong place in the cultural life of the Uzbek people and have been widely used in their cultural life. Therefore, it is appropriate to call these instruments Uzbek folk instruments. In the works of Abdul Fazl Boyhaqi (XIV century) the names of stringed mizrobli (rud, barbad, tanbur), tambourine and percussion instruments (trumpet, litavra and drum) are mentioned.

It is known that in the past, the system of writing responses to the works of poets ("nazira") was widely used in Eastern literature. Many "Khamsa" were created in this way. In his epic Sab'ai Sayyar (one of the epics of Hamsa), Navoi reinterpreted the ancient legend of Bahrom Gor. The protagonist is a duster named Dilorom. The poet embodied his instrument as a symbol of music.

Zahriddin Muhammad Babur (1483-1530) admits that Alisher Navoi in his time helped many oud players to show their talents. The names of Uzbek folk instrument performers are mentioned in the Boburnoma. Babur also mentions such talented performers as Shah Kulmi-Gijjaki, Husayn Udi, Khoja Abdullah Marvarid Qanuni.

During the Navoi period, the performance of nay, ud, gijjak, kanun, karnay, surnay, drums, doyra, and chang was widespread. They were all used equally in both ensemble performance and solo performance. Dust stood out as a solo instrument.[3]

Comparing the data of the written monuments of 
CURRENT RESEARCH JOURNAL OF PEDAGOGICS 2(12): 82-89, December

2021 DOI: https://doi.org/10.37547/pedagogics-crjp-02-12-17

ISSN 2767-3278

(C)2021 Master Journals

Crossref do: 81 Google

Accepted $18^{\text {th }}$ December, 2021 \& Published 23 th December, 2021

the XV-XVII centuries, it can be concluded that by this time, the culture of performance on folk instruments in Central Asia has matured. Performers of Uzbek folk instruments have also created their own musical works. At that time, there were skilled chang, ud, gijjak, kanun, nay, tanbur, bulamon performers and mature singers, who formed their own ensembles. Solo performance is also developed. In his memoirs, Wasifi cites the name of Haji Abdullah Marvarid, a lawmaker who invented a brilliant style. The melodies and songs he composed were popular among the people. Thus, in the fine arts and literary heritage of the XIV-XVII centuries there was a rich material confirming the stability of the main types of musical instruments, which have their roots in the distant past.

Restoration and development of the makom genre in the art of music performance In the XVII-XIX centuries no major works with detailed descriptions of instruments were created. This is more due to the growing feudal dispersal. The huge state is divided into separate khanates (Bukhara, Khiva, Quqon khanates). This was reflected in the development of the art of music. Uzbek music culture began to acquire local features. Unique musical instruments were formed. From the types of music - maqoms have since developed in a specific direction in each khanate. Status executors made changes as needed. Nevertheless, they retained the general characteristics of music. Each performer took a creative approach to the performance of the maqom, adding unique aspects to the performance of the music. The tradition of preserving musical instruments orally is one of the main features of the status quo, without which it is difficult to imagine its survival and final development. In each khanate new types of folk music were created in a specific direction; festive, melodies, folk spectacle melodies (dorbozlik, puppetry) new type of dance melodies. These melodies differed from each other by their cheerfulness and joy and attracted a wide audience.[4]

In the late seventeenth and early nineteenth centuries, the following new types of folk and professional music began to develop in Uzbek musical culture; big song, big game, Shodiyona, Navruz, Mavrigi, Shashmaqom, Chor maqom (it included Dugoh, Husseini, Chorgoh, Bayot, Gulyori-Shahnoz). Different musical ensembles have been formed depending on the available musical instruments and performers. In many cases, the ensemble of folk instruments includes musical instruments such as gijjak, tanbur, dutor, chang, nay, koshnay, doira.

Shashmaqom, which consists of six series of works in music, was especially popular. It is the result of the long development of professional music in the form of suites (series) of the peoples of Central Asia. I.Rajabov writes: Shashmaqom consists of six different systems of fret, each of which, in turn, is divided into the following maqoms (parts), consisting of sections of mushkilot (instrument) and prose (ashula): "Rost", "Buzrug", "Navo", "Dugoh", "Segoh", "Iraq" ... Each status contains 20 to 40 large and small parts. In total, there are about 250 pieces of prose and prose in the category. The execution of one status lasted several hours.[5]

Folk instruments develop in close connection with folk oral art and classical literature. Perceptions of folk instruments are enriched by the expressions of musical instruments in works of art, the image of musicians in book miniatures. The names of more than 60 folk instruments are mentioned in the works of Firdavsi, Saadi, Navoi, Dehlavi.

The ceremonies were performed mainly in the presence of palace dignitaries at a specific time or under certain conditions. It is even known that a special competition of talented singers was organized (especially in the performance of peaks, as well as in the weaving of unique new 
CURRENT RESEARCH JOURNAL OF PEDAGOGICS 2(12): 82-89, December

2021 DOI: https://doi.org/10.37547/pedagogics-crjp-02-12-17

ISSN 2767-3278

(C)2021 Master Journals

Crossref do: 81 Google

Accepted $18^{\text {th }}$ December, 2021 \& Published 23 th December, 2021

parts).

The revival and development of the makom genre in the art of music performance continued. The status was inextricably linked with folk songs according to its laws of melody and rhythm, and differed only in the breadth of its scope. Typically, each status is divided into two major parts.

The first is the part that is only performed on the instruments and is called the difficulty, and the second is the part that is sung with the instruments and is called the prose. Nasr also included dance tunes.

Among the musicians, there was an attempt to create a notation system with a special character system that recorded the sounds of the music. The poet-musician Pahlavon Niyaz Mirzaboshi (Komil Khorezmi 1825-1879) was able to do this. Talented musician Pakhlavon Niyaz Mirzaboshi, a skilled drummer and drummer, was amazed to see musicians playing music on the notes during the trip. As soon as Mirzaboshi-Kamil Khorezmi returned to Khorezm, he began to write down his intentions with inspiration.

Muhammad Yakub Kharratov (1867-1939), a student of Pakhlovon Niyaz Mirzaboshi Kamil, was a famous drummer. He had mastered not only the art of painting, but also the art of calligraphy. Muhammad Yakub Kharratov (Matyokub Kharratov), a musician of the palace folk instruments ensemble led by the talented musician Kamil Khorezmi, took part in composing the tanbur notation and recording Khorezmian maqoms. He received Khorezmian maqom series from his teacher and made a great contribution to their preservation.

The creative and performing activity of the famous tanbur player and singer Niyazkhoja Haji, who worked in the palace of Muhammad Rahimkhan (1806-1825), took place in Khiva. He paid great attention to Khorezmian musical culture.

According to Matyokub Kharratov, Niyazkhoja went to Bukhara to study Shashmaqom. When he returned from Bukhara, the Bukhara maqoms were mastered by Khiva musicians and began to spread in Khorezm. Famous Khorezm musicians Muhammadrahim Feruz, Kamil Khorezmi, Mirzo Muhammadrasul and others, in cooperation with Niyazkhoja, added new musical instruments to the maqoms and enriched them.[6]

In the second half of the 19th century, the city of Kokand became a gathering place for famous musicians. Here, under the leadership of Master Khudoiberdi, a unique school was created to study the school of performance in Uzbek folk instruments. Fergana instruments began to actively master the Bukhara shashmaqom. His father, Jaloliddin Nosirov (1845-1928), was a maqom performer, a well-known teacher, a musician, and a master drummer. He first learned the science of music from his mother, and then from his father, who was a brilliant scholar of the maqams and a skilled performer. For many years, Ata-Jalol Nosirov was the permanent leader and singer of the Uzbek folk ensemble in the palace of Amir Alimkhan (Bukhara), Amir Muzaffarkhan (Shahrisabz), Amir Otajonlar (Karmana, now Navoi). he was a scholar, a drummer from Bukhara. Hoji Abdulaziz Rasulov (1852-1936) was one of the famous performers of Uzbek and Tajik music, a student of the talented tanbur player Hoji Rahimkul. In 1888 he went to Bukhara. There, under the leadership of Ota-Jaloliddin Nazirov, he studied Shashmaqom perfectly for a year. Rasulov actively promoted Uzbek folk music and status in Fergana, Samarkand and Tashkent. He made a significant contribution to the development of Uzbek folk instruments as a tanbur player, dutar player and singer, and won the love of the people and the music community.

The musicians mentioned above began their 
CURRENT RESEARCH JOURNAL OF PEDAGOGICS 2(12): 82-89, December

2021 DOI: https://doi.org/10.37547/pedagogics-crjp-02-12-17

ISSN 2767-3278

(C)2021 Master Journals

Crossref do: 81 Google

Accepted $18^{\text {th }}$ December, 2021 \& Published 23 th December, 2021

careers and developed creatively in their time. They were all enlighteners, teachers of young musicians. Their pedagogical views and teachings are a new pedagogical source of performance on Uzbek folk instruments and are preserved as an immortal heritage.

Development of the performing arts in 19171945 After 1917, the Uzbek musical art began to develop rapidly and enthusiastically. In the first decade, certain achievements were made in the fields of music education, folklore, and performing arts.

Great work has been done at music schools - the Turkestan People's Conservatory in Tashkent (1918) and its branches in Samarkand, Fergana (1919), Bukhara (1920). They were taught to play Uzbek folk instruments as well as some European musical instruments (piano, violin and tambourine). Although these music schools were not literally conservatories, those who did not have the opportunity to study the science of music culture in the past were taught the simple science of music and the performing arts. Due to this, the hobby of music has spread in many cities of the young republic.

Founder of Uzbek art, playwright, composer, teacher, public figure Hamza Hakimzoda Niyazi made a great contribution to the development of music. The traditions created by folk musicians and performers of the period up to 1917 were formed and continued in the works of the next generation of instruments. Musicians-performers began to work in reorganized cultural and educational organizations.

Famous tanbur player and singer Shorahim Shoumarov in 1919 formed an ensemble of folk instruments at the boarding school "Namuna" in Tashkent. This ensemble later served as the basis for the establishment of the Tashkent Music College.

In the 1920s, such musical groups as "Blue Shirt",
"Art Girls", "Sanoyi nafisa" were formed in schools, factories and rural areas. The organized creative teams included ensembles of folk instruments consisting of naychi, changchi, dutarchi, tanburchi, gijjakchi, doyrachi, drummers and Kashgar rubab musicians.

Ensembles of folk instruments are also formed in Fergana, Andijan and Samarkand. Famous musicians Olim Kamilov, Tukhtasin Jalilov, Ahmadjon Umirzakov, Yusufjon Shakarjanov, master Ruzmat Isaboev, Matyusuf Kharratov, master Toyir Marufjon Toshpulatov, Muhiddin Mavlonov led them. Thanks to their effective work, many people enjoyed the performing arts on Uzbek folk instruments. In 1936, on the occasion of the Decade in Moscow, Qori Yakubov was commissioned to establish the State Philharmonic, where he was appointed the first director of the Philharmonic. Due to the determination of Qori Yakubov and other musicians, the decision was made to establish the Tashkent State Conservatory.

The creative activity of Yunus Rajabi (18971976), a follower of the traditions of Uzbek folk music, a talented Tashkent folk instrument player-dutar player, tanbur player, naychi, was characterized by a wide range of enlightenment musical and social features. The most remarkable result of Yunus Rajabi's many years of creative activity was the recording and preparation for publication of five volumes of Uzbek folk music.

In 1927, Yunus Rajabi formed a national ensemble of folk instruments consisting of 12 musicians (singers and musicians) under the Radio Committee of Uzbekistan. The ensemble included famous musicians from Tashkent at that time - neighbor Khairulla Ubaydullaev, dutar players Abdusoat Vahobov, Orif Kasimov, tanbur players Rixsi Rajapov, Mahsudkhoja Yusupov, drummers Imomjon Ikramov, Nabi Hasanov, Mahmud Yusupov, drummers Dadaali Soatkulov, 
CURRENT RESEARCH JOURNAL OF PEDAGOGICS 2(12): 82-89, December

2021 DOI: https://doi.org/10.37547/pedagogics-crjp-02-12-17

ISSN 2767-3278

(C)2021 Master Journals

\section{Crossref do) 81 Google}

Accepted 18 ${ }^{\text {th }}$ December, 2021 \& Published 23 ${ }^{\text {th }}$ December, 2021

Dadaali Soatkulov, Dadaali Soatkulov. , Mahamatjon Rasulov, doyrachi Dadahoja Sottiev. Along with Uzbek folk melodies, his repertoire includes modern composers, including Yunus Rajabi's "Chorgoh", "Kochabogi", "Bayot", "Birlanish", "Fabrika", "Galaba", "Hammamiz", "Ilgor", "Mirzadavlat" had works. Later, the ensemble included famous singers of the republic Mulla Tuychi Tashmuhamedov from Tashkent, teacher from Bukhara Halim Ibodov, dutar player and singer from Samarkand Abdurahmon Umarov, drummer and singers Matyokub Kharratov, Safo Mugoniy, Tashkent Nazira Ahmedova. Currently, the ensemble's repertoire includes difficult and prose parts of "Shashmaqom", "Nasurulloi", "Navruz Sabo", "Talqini ushshak", "Sarvinozi talqincha", as well as composers' "Wake up", "Our village", "Long live", Our collective farm".

In 1930, the Tashkent Higher School of Music was opened, and in 1936, the Tashkent State Conservatory, the first music university in Central Asia, was opened on its basis. The 19361937 academic year was a very important period for the development of music education in the field of performance on folk instruments. At the same time at the Tashkent Music School named after Hamza on the initiative of AIPetrosyans such teachers as Y.Rajabi, A.Daroshev, A.Mansurov, B.Gienko, N.Krestyanin, V.Marsinkovsky, A.Makhsudov, O.Kasimov were accepted. began to teach performance on Uzbek folk instruments on the basis of the notation system. Sh.Shoakramov, A.Gafurov, M.Yunusov (powder), S.Yuldoshov, G.Qodirov (tanbur), A.Ilyosov, M. Azamov and others were among their first students.

The growth of performance culture in Uzbek folk instruments, the development of works by world composers, the active creative activity of Uzbek composers in creating special works for folk instruments became an important basis for the further development of performing arts on
Uzbek folk instruments. At the same time, he put on the agenda the issue of thorough and perfect training of highly qualified scientific, pedagogical and executive personnel.

The recent rise in performance on Uzbek folk instruments is closely linked with the activities of the Tashkent Conservatory. Since 1948 in music universities of our country, including; The current Uzbek State Conservatory (former Tashkent State Conservatory named after M. Ashrafi) has also started teaching folk instruments.

A.I.Petrosyans headed the department of Uzbek folk instruments (as part of the orchestra faculty), selected students and developed curricula. VA Uspensky, MA Ashrafiy, AI Petrosyans, IP Blagoveshchensky, BF Gienko, GG Sobitov played an important role in the establishment of professional training in the performance of Uzbek folk instruments at the Tashkent State Conservatory.

In the first academic year of 1948-1949, 13 musicians of the orchestra of folk instruments of the State Philharmonic of Uzbekistan were admitted to the conservatory. 10 of them: Nazir Nigmatov (neighbor), Abbos Bahromov, Alexander Evdokimov (prima-rubob), Lali Sultanova, Mirzaev, Buriboy Mirzaakhmedov (Kashgar rubob), Mahamatjon Asilov, Obid Kholmukhamedov (gijjak), Anvar Liviev (doyra) for the 1st year accepted. Ahmadjon Adilov (chang), Valentina Borisenko (prima rubobi) and Feoktist Vasilev (kashkar rubobi), graduates of the Tashkent Music School named after Hamza, were admitted to the 2 nd year.

Muhammadjon Mirzaev (born in 1913) is the most famous Rubob player in the republic. He graduated from the conservatory in the class of Kashgar rubobi under the direction of A.I. Petrosyans. In addition to working in the Philharmonic Orchestra since 1951, he has coached young performers to study the heritage 
CURRENT RESEARCH JOURNAL OF PEDAGOGICS 2(12): 82-89, December

2021 DOI: https://doi.org/10.37547/pedagogics-crjp-02-12-17

ISSN 2767-3278

(C)2021 Master Journals

\section{Crossref do) 8 Google}

Accepted 18 ${ }^{\text {th }}$ December, 2021 \& Published 23 ${ }^{\text {th }}$ December, 2021

of Uzbek folk music. In collaboration with People's Artists H. Mavlonova and M. Turgunbaeva, she created lyrical dance melodies such as "Spring Waltz", "Yangi Tanovar", "Gulnoz", "Dilbar", “Gulkhumor”, "Dildor". Among his songs, "Shirmonoy", "Golden Box", "Three Friends" are especially popular. Mirzaev is a People's Artist of Uzbekistan, a member of the Composers' Union of Uzbekistan and a recipient of several awards. He was one of the first rubab players to create an emotional and bright style base in rubab performance (later developed by young performers). Mirza Hakimovich Toirov (born in 1930). He was one of the first graduates of the conservatory with a degree in flute (1956). In collaboration with his teacher AI Petrosyans, he created the Nay School textbook. This manual has made it possible to open nay classes in all music schools in Uzbekistan, as well as in neighboring republics. Since 1957, M. Toirov worked at the Department of Performing Arts, first as a teacher, then as an associate professor. At the same time, he participated in the orchestra of folk instruments named after T. Jalilov. M. Toirov participated in the All-Union Competition of Music Performers (1957) and the VI World Festival of Youth and Students (1957), decades of Uzbek art in Estonia and the CIS (Moscow, Kazakhstan, Azerbaijan, Turkmenistan, Tajikistan). M.Toirov has brought up several talented pipers. His students I.Kasimov, 0.Azizov, Sh.Ahmadjanov, R.Kholmirzaev, K.Yusupov, A.Abdurashidov became the winners of republican competitions. M.Toirov Honored Artist of Uzbekistan (1969). He has been a professor at the conservatory since 1987.

Fozil Matyusupovich Kharratov (1926-1971) was one of the most famous dustmen. He learned his first lessons in music and performance from his father, the famous drummer Matyusuf Kharratov. The father (M.Kharratov) at the request of the child makes him a new powder belonging to the series of semi-chromatic sounds. In 1942, the family of F. Kharratov moved to Tashkent. Fozil previously worked here in the mixed music ensemble of the Tashkent State Circus. In 19501955 he studied at the Tashkent State Conservatory in the class of A. Odilov's dust instrument. He then taught at the conservatory for some time. Among his students are such wellknown performers as G. Nematov, F. Shukurova, T. Khojamberdiev. F.Kharratov is a prize-winner of the VI World Festival of Youth and Students in Moscow, Honored Artist of Uzbekistan (1964). He was awarded the Order of the Badge of Honor.

Feoktist Nikiforovich Vasilev (1919-1987) was one of the first professional Kashgar rubabi performers. In 1937 he entered the Tashkent Music School named after Hamza. From 1938 he was a musician of the Uzbek Philharmonic Orchestra of Folk Instruments. During World War II, he worked in the song and dance ensemble of the Turkestan Military District. He graduated from the conservatory under the direction of A.I. Petrosyans (1952). From 1949 he taught at the conservatory in the specialty of Kashgar rubabi, dutar, tanbur. Famous rubab players such as S.Takhalov, A.Bobokhonov, G.Ergashev, T.Rajabov, K.Usmanov were brought up under him. Feoktist Nikiforovich in his scientific-methodical work (textbook "School of Rubob") developed a systematic teaching method for learning to play the rubab "Etude and exercises for the Kashgar rubab. From 1983, F. Vasilev worked as an acting professor. Feoktist Nikiforovich's name is associated with Uzbek musical culture.[7]

$\mathrm{He}$ is closely connected with the Tashkent Conservatory, where he has been a coach for almost 40 years. Valentina Yakovlevna Borisenko (1919-1990) began her career as a musician in the orchestra of folk instruments of the State Philharmonic of Uzbekistan (1939). Prima was known as a performer and teacher in the rubobi specialty. After graduating from the Hamza Music 
CURRENT RESEARCH JOURNAL OF PEDAGOGICS 2(12): 82-89, December

2021 DOI: https://doi.org/10.37547/pedagogics-crjp-02-12-17

ISSN 2767-3278

(C)2021 Master Journals

Crossref do: 81 Google

Accepted 18 ${ }^{\text {th }}$ December, $2021 \&$ Published 23 $3^{\text {th }}$ December, 2021

School (1948), Borisenko worked as a concertmaster in the orchestra's string-andstring instruments. He graduated from the Conservatory with a degree in Prima Rubobi under the direction of IG Blagoveshchensky (1952). He then continued to work in the orchestra. From 1950 he worked as a teacher at the Tashkent Conservatory, and from 1962 as an associate professor of folk instruments. Among Borisenko's famous students are such performers as A.Malikov, G.Salaeva (Obidova), B.Yuldashev, M.Rahimov, B.Azimov, Sh.Janaydarov, A.Dadamuhamedov.

Sulaymon Manievich Takhalov (born in 1942) is one of the rubab players with excellent performance technique and special sound charm, mastering both traditional and academic performance methods. After graduating from the conservatory, F.N. Vasilev (1958) taught Kashgar and Afghan rubabs and tanbur. S. Takhalov took part in the VI World Festival of Youth and Students in Moscow (1957). He is the owner of large-scale research work in the field of improving the notation and description of Uzbek folk music of the All-Union Competition of Performers of Folk Instruments. He is the author of the textbook "Fundamentals of teaching Afghan rubab, playing". S.Takhalov has been an associate professor since 1985, and since 1988 he has been awarded the degree of Doctor of Arts, Professor.

Abdusalom Malikovich Malikov (1939-1979). He served as an associate professor. Special attention should be paid to the creative work of A.Malikov on the specialty rubob-prima in 60-65 years at the conservatory under the direction of V.Y.Borisenko. From 1967 he worked at the Department of Folk Instruments. Winner of the I Republican Contest (1971).

Gulomkodir Ergashevich Ergashev (born in 1946). Former student of the Tashkent Conservatory (1969). A student of F.N. Vasilev, an Afghan rubobi performer, he often participates in concerts with various programs. From 1967 he worked as a teacher at TDK, from 1988 as an associate professor of the department.

\section{ReFERENCES}

1. Abdullaeva C. Narodnie muzikalnie instrumenti Azerbaydjana. Baku. 1972.P.53.

2. Rajabov I. On the issue of status. Tashkent. 1963. - P. 23.

3. Fitrat A.Uzbek classical music and its history. Tashkent 1993. - P. 55.

4. Fitrat A. Uzbek classical music and its history. Tashkent. 1993. - P.10.

5. Rajabov A. Namai Niyogon. Dushanbe. Irfon.1988. - P.63.

6. Odilov A., Lutfullaev A. Chang. Tashkent. 2002.- P.22

7. Karomatov F. Uzbek instrumental music. Tashkent. 1972. - P. 39 